\title{
The Role of Education in Overcoming Moral Problems
}

\author{
I Ketut Sudarsana ${ }^{1}$, Indrya Mulyaningsih ${ }^{2}$, Putu Santi Oktarina ${ }^{3}$, Ifit Novita Sari ${ }^{4}$, I Putu \\ Andre Suhardiana $^{5}$, I Gede Januariawan 6 , I Gde Rai Parsua ${ }^{7}$, Diah Puji Nali Brata ${ }^{8}$, Rr. \\ Agung Kesna Mahatmaharti ${ }^{9}$, Aan Aswari ${ }^{10}$ \\ \{'iketutsudarsana@uhnsugriwa.ac.id\} \\ 1,3,5,6,7 Universitas Hindu Negeri I Gusti Bagus Sugriwa Denpasar, Bali, Indonesia, ${ }^{2}$ Institut Agama Islam \\ Negeri Syekh Nurjati Cirebon, Indonesia, ${ }^{4}$ Social Science Education Program, Post Graduate Program, \\ Universitas Kanjuruhan Malang, Malang, Indonesia, ${ }^{8,9}$ Civil Educatin, STKIP PGRI Jombang, \\ Jombang, Indonesia, ${ }^{10}$ Universitas Muslim Indonesia, Makasar, Indonesia
}

\begin{abstract}
Education of a nation will never stop and finish. Like broken, it grows lost to change, finishes from solving a problem, other problems arise which sometimes are not less complicated. Likewise, the results of an existing educational problem-solving strategy often arise new problems that are far more complicated than the initial problems. That is why the development of education sector will never have a limit. As long as humans exist, the problem of education will never be lost from the discourse of a nation. Therefore, the education sector development agenda always exists and develops in accordance with the dynamics of the life of a nation.
\end{abstract}

Keywords: Education; Moral Problems

\section{Introduction}

Education in the history of human civilization is a very urgent component of life. This activity has been going on from time to time, with very rapid development, education has experienced rapid development. Education is a conscious effort to prepare students through guidance, teaching activities or their future roles [1]. To improve the quality of education a more innovative learning strategy is needed so that the teaching and learning process is more directed. Because with quality education will produce quality output that is better prepared for the future.

The Indonesian nation has never stopped building the education sector so that the quality of its human resources is able to compete globally. If so, competitive superior issues for graduates of an educational institution need to be studied and fought for in the teaching and learning process by all educational institutions in the country so that the relevant educational institutions are able to uphold accountability to their environment. To be able to do such things, educational institutions need to make various efforts towards continuous improvement of quality. Without continuous improvement in quality, education development will be trapped in a momentary effort and only be reactive patchwork. Conversely, so that the education sector is able to encourage all processes of nation empowerment, it must be planned and programmed systematically and proactively. Educational institutions can ground their programs to empower students. Not the other way around, students must be controlled so that they are suitable and in accordance with the programs and processes that already exist in an 
educational institution. Such learning activities will not be able to help students to find their identity more independently. Finally, students will not be able to develop imaginative abilities that are useful to foster innovative creativity. Reformative efforts in the education process are also very necessary so that our education does not work in place.

Human life is never separated from social and cultural elements. Throughout the activities of human life, its activities cannot be separated from other human groups. Because it is said that humans are social beings because they require presence and assistance and the participation of others. This social culture is reflected in the activities of a group of people together. The things that humans do, how to do it, the desired form of work is an element of a culture. So, the social aspect in terms of the relationships between individuals, between communities and cultural aspects in terms of the human education process through the material being studied, how to learn, how the learning style, forms of learning and teaching.

Education is essentially a conscious and deliberate activity that is fully carried out by adults to children so that interaction between the two of them arises so that the child reaches maturity that is aspired to be carried out gradually in all complementary environments (household, school, community) social elements are natural individual aspects that have existed since humans were born. Langeveld said that every baby born is renewed with the potential of sociality or the ability to get along, communicate with each other which essentially contains the elements of giving and receiving each other. Social activity is reflected in daily relationships, when there is social interaction between individuals with each other or individuals with groups, as well as between groups. In this interaction there are interrelations that influence each other [2].

Factually, educational activities are activities between humans, by humans and for humans. Therefore, the discussion of education is never separated from the human element. From some opinions about education proposed by education experts generally agree that education is given or organized in order to develop all human potential in a positive direction. Education, basically is the process of communication which contains the transformation of knowledge, values and skills, inside and outside school which lasts for life, and generation after generation. Education as a human phenomenon and at the same time a conscious effort, in it is inseparable from the limitations that can be attached to students, educators, the interaction of educators, as well as on the environment and educational facilities.

At present, Indonesian people experience a shift in aspects of morality. In the era of globalization and reform like today, we all can feel together, that freedom of opinion and behavior is so widespread, because it is too free and its fulgence in the appearance and reporting, to the extent that many young people do not pay attention to morality, courtesy, ethics and character as the Eastern custom we glorify. The electronic media in the form of television, as well as the print media that we witness and read every day, both displaying constructive criticism and entertainment shows that indulge in disobedience are so widespread and free in society. This will directly affect the morale and behavior of the viewers or readers, especially teenagers who do not have strong religious knowledge. In this case, education plays an important role in overcoming morality problems faced by society. Therefore, through this article the author reveals how the role of education in the issue of morality. 


\section{Method}

This research is a qualitative descriptive study. Descriptive method is used to explain and direct research objectives in an effort to find theories, are descriptive, more concerned with the process rather than the results, discussing the study with a focus on the research design agreed by the researcher as well as the object and research objectives. The process of data collection is done by: (a) recording data on a data card, recording and capturing the entire essence of the data then recording on the data card, using sentences compiled by the researchers themselves. (b) Recording data in quotation, i.e. recording data from data sources directly and precisely. (c) Record data synopically, i.e. records data from data sources by making an overview or summary.

\section{Result and Discussion}

Definition of morality, Morals are teachings about good and bad that are generally accepted regarding actions, attitudes, obligations and so on. The definition of morality also has the same meaning as the definition of morality, character, and morality. Moral actually contains two different aspects, namely the inner and outer aspects. Good people are people who have a good inner attitude and do good deeds. In other words, morals can only be carved appropriately if both aspects are considered. People can only be assessed appropriately if their hearts and actions are reviewed together [3].

Morality is a quality in human actions that shows that the action is right or wrong, good or bad. Morality includes an understanding of the good and bad of human actions. Morality can be objective or subjective. Objective morality views action as merely an act that has been done, free from the voluntary influence of the offender. Apart from all the special circumstances of the perpetrator that can influence or reduce self-control and ask whether people who fully control themselves are allowed to voluntarily want the act. Subjective morality is morality that views action as an act that is influenced by the understanding and approval of the individual actor. Besides that it is also influenced, conditioned by his background, education, emotional stability, and other personal traits. This shift occurs in the public's view of the concept of morality itself. Morality here is understood as a concept of morality or goodness or how well something has been constructed by society. Shifting society's morality is more or less influenced by the development of science. A little remembering the story of Socrates, he was once concerned and cried at the discovery of scientific progress. The concern of the Greek philosopher which contained concern and even a deep fear of the Greek authorities at that time. Then Socrates tried to incorporate moral teachings into the forces and strengths of politics. Intutitive and cognitive abilities, Socrates argued to the people so as to break the ruler's poems about the importance of morality in the order of life of the nation and state [4].

Moral education is very necessary for humans, because through education, moral development is expected to be able to run well, in harmony and in accordance with the norms for human dignity itself. In Indonesia moral education has existed at every level of education [2]. In Elementary Schools, the development of moral education has never departed from the noble values that exist in the moral order of the Indonesian nation which is clearly stated in Pancasila as the basis of the state. The Pancasila Moral Education, which has been taught from basic education certainly has a very noble goal, is nothing but to shape the country as a 
religious individual, has a sense of humanity, is tolerant for the sake of unity, upholds the values of deliberation for the people and essential justice. Departing from the above objectives, in its implementation there are three important factors in moral education in Indonesia that need to be considered, namely: (1) Students who actually have a level of awareness and difference in the development of uneven moral awareness, it is necessary to identify which leads to an understanding regarding the condition of moral development of the students themselves. (2) Pancasila (moral) values, based on the stages of awareness and human moral development, it is necessary to know also the level of students' ability levels. It is important to remember that with different stages and levels, all moral values contained in the moral education have certain limits to be able to be embedded in the moral awareness of students. (3) Teachers as facilitators. By paying attention to these three things, the process of human moral development that runs in the course of education will certainly run according to the stages of moral development in each human being.

Educators, as part of education should have a role in carrying out moral education, namely by: (1) An educator must be a model as well as being a mentor of students in realizing moral values in life in school. Without a teacher as a model, it is difficult to realize a social institution (school) that can realize cultural values. (2) The school community must be a moral society. Schools and campuses are not only to improve intellectual abilities, but also to foster honesty, truth and dedication to humanity.

The role of education (education) in overcoming moral issues is to guard generations from childhood. Develop their lifestyle, feelings and thoughts in accordance with nature, so that they become a solid and perfect foundation in society [5] [6] [7]. Because education goes hand in hand with children's development, education will greatly affect the child's soul and development and will become part of the personality for later life. Education is the most important tool to protect yourself and maintain positive values. Education carries two main tasks that are mutually contradictory, namely to preserve and make changes.

Moral Education Approach and Strategy, according to the Competency Based Curriculum (KBK), approaches that can be used to implement moral education, namely:

a) Inculcation Approach

This approach strives for students to recognize and accept values as their own and to be responsible for the decisions they make. The method used in this approach is exemplary, positive and negative reinforcement, simulation, and role playing.

b) Cognitive Moral Development Approach

This approach emphasizes on various levels of moral thinking. The teacher can direct the child in applying the process of moral thinking through discussion of moral issues so that students can make decisions about their moral opinions.

c) Values Analysis Approach

This approach emphasizes that students can use the ability to think logically and scientifically in analyzing social problems related to certain values. The method that can be used in this approach is a focused discussion that demands argumentation, affirmation of evidence, affirmation of principles, analysis of cases, debate, and research.

d) Value Clarification Approach

This approach aims to foster awareness and develop students' abilities in identifying their own values and the values of others. Ways that can be used are role playing, simulations, in-depth analysis of their own values, activities that develop sensitivity, activities outside the classroom, and group discussions. 
e) Action Learning Approach

This approach aims to develop students' abilities in carrying out social activities and encourage students to see themselves as creatures who constantly interact in social life. The methods that can be used are project activities in school, interpersonal relationships, practices of community life and organization [8] [9] [10].

The strategies that can be used in character education are moral education as a substance and practical education in the school environment, integrated in a number of relevant subjects and the socio-cultural climate of the school. Organizing character education in the school curriculum can be done through several alternatives. Involvement of all components of education implementation, especially teachers, principals, education administrators, curriculum developers, textbook writers and teacher education institutions according to their position, roles and responsibilities.

\section{Conclusion}

The quality of human resources is strongly influenced by education. Thus, the field or world of education is the field of being the backbone of the implementation of national development. The purpose of education, especially in Indonesia is to form a whole person who loves Pancasila, driven by affection development. This specific objective can only be handled with Indonesian-style education in accordance with Indonesia's conditions, and with the implementation of education using the concept of the system.

The education system in Indonesia is organized by relying on four competencies that must be mastered and possessed by the teaching staff. The four competencies are professional competence, social competence, personality competence, and pedagogic competence. Therefore, these four competencies are the most important thing to be mastered by the teaching staff in order to achieve the educational goals in Indonesia. From a human point of view, education is the process of socialization, namely socializing values, knowledge and skills in life. As quoted by Khoiron Rosyadi, Emile Durkheim in his work Education and Sociology said that education is a human product that establishes the perpetuation of human life itself, namely being able to live consistently over the threats and challenges of the future. Morality is a quality in human actions that shows that the action is right or wrong, good or bad. Morality includes an understanding of the good and bad of human actions.

\section{References}

[1] O. Hamalik, Kurikulum dan Pembelajaran. Jakarta: Bumi Aksara, 2001.

[2] A. Abu, Psikologi Belajar. Jakarta: Rineka Cipta, 2003.

[3] Nasrun AR, "Psikologi Belajar," Al-Fikrah Julnal Kependidikan Islam., 2015.

[4] R. Mudyahardjo, Pengantar Pendidikan. Jakarta: PT Raja Grafindo Persada, 2007.

[5] C. Budiningsih, Asri, Belajar dan Pembelajaran. Jakarta: Rineka Cipta, 2005.

[6] M. S. Hanafy, "Konsep Belajar dan Pembelajaran," J. Lentera Pendidik., 2014.

[7] W. Sanjaya, Strategi Pembelajaran Berorientasi Standar Proses Pendidikan. 2010.

[8] E. Mulyasa, "Kurikulum tingkat satuan pendidikan: Sebuah panduan praktis," Bandung PT Remaja Rosdakarya, 2007.

[9] J. S. Brubacher, "Konsep dan teori kurikulum dalam dunia pendidikan," Tata McGraw Hill 
Publ., 1978

[10] R. Nurmalasari, R. Dian, P. Wati, P. Puspitasari, W. Diana, and N. K. Dewi, "Peran Guru Dalam Implementasi Kurikulum 2013,” J. Berk. Progr. Pascasarj. UM Malang, 2016. 